\title{
Myeloma as a Second Malignancy following AML: Is a Second Allo Equivalent to Auto?
}

\author{
Sule Mine Bakanay, ${ }^{1}$ Esin Serbest, ${ }^{2}$ Klara Dalva, ${ }^{1}$ Isinsu Kuzu, ${ }^{3}$ and Meral Beksac ${ }^{1}$ \\ ${ }^{1}$ Stem Cell Transplantation Unit, Hematology Department, Ankara University Medical School, Dikimevi, 06590 Ankara, Turkey \\ ${ }^{2}$ Tissue Typing Laboratory, Stem Cell Transplantation Unit, Hematology Department, Ankara University Medical School, Dikimevi, \\ 06590 Ankara, Turkey \\ ${ }^{3}$ Department of Pathology, Ankara University Medical School, Dikimevi, 06590 Ankara, Turkey
}

Correspondence should be addressed to Sule Mine Bakanay, sulemine@yahoo.com

Received 30 April 2012; Accepted 31 May 2012

Academic Editor: Thomas R. Chauncey

Copyright () 2012 Sule Mine Bakanay et al. This is an open access article distributed under the Creative Commons Attribution License, which permits unrestricted use, distribution, and reproduction in any medium, provided the original work is properly cited.

We report a young male patient who developed plasma cell myeloma/plasmacytoma 11 years after having received an allogeneic hematopoietic cell transplantation for AML. The patient received a second transplantation from the same donor without immunosuppression and developed graft-versus-host disease (GVHD). Our observation has two aspects that warrant attention: first, insufficiency of long-term tolerance to prevent GVHD in the absence of immunosuppression and second, a stromal or genetic susceptibility to develop hematologic malignancies despite of a complete donor-type chimerism.

\section{Introduction}

Allogeneic hematopoietic cell transplantation (HCT) is the only therapy successful in achieving cure for hematological malignancies. However, long-term survivors of allogeneic HCT face the risk of developing second malignancies, mainly the posttransplant lymphoproliferative diseases (PTLDs), secondary MDS/AML, and secondary solid malignancies [1]. Posttransplant lymphoproliferative disease presenting as plasma cell myeloma is extremely rare and represents a treatment challenge especially in presence of complete donortype chimerism.

\section{Case Presentation}

A 26-year-old male patient was diagnosed as AML-M2 in 1995. Following an induction regimen he achieved complete remission (CR) and received an allogeneic peripheral blood stem cell transplantation from his 37-year-old HLA identical brother in 1997. The conditioning regimen consisted of busulfan and cyclophosphamide, and the GVHD prophylaxis was done with cyclosporin and short-term methotrexate. He did not develop any acute or chronic GVHD and remained in CR with complete donortype chimerism until 2008 when he was admitted to the neurosurgery clinic with back pain. The vertebral MRI revealed a tumor invading the 6 th thoracic vertebrae causing pathological fracture. The tumor was completely excised, and the pathological evaluation was consistent with $\mathrm{CD} 38^{++}$ and $\mathrm{CD} 117^{+}$atypical plasma cell infiltration with kappa monoclonality. He had IgG kappa monoclonal gammopathy on immune electrophoresis and an elevated erythrocyte sedimentation rate along with a mild anemia and normal renal function tests. Bone marrow (BM) examination revealed 9\% plasma cells with $\mathrm{CD} 38^{+} \mathrm{CD} 138^{+} \mathrm{CD} 19^{-} \mathrm{CD} 56^{-}$ $\mathrm{CD} 44^{+} \mathrm{CD} 28^{-} \mathrm{CD} 20^{-}$immunophenotype and kappa predominance. The cytogenetic study did not detect any abnormality. Bone marrow chimerism analysis was consistent with 100\% donor type in both T-and non-T-cell lineages. Chimerism study was also done with the DNA extracted from the plasmacytoma and revealed $18 \%$ donor and $82 \%$ recipient cells (Figure 1). The presence of EBV could not be demonstrated in $\mathrm{BM}$ or plasmacytoma by in-situ hybridization for EBV early RNA as well as PCR analysis of EBV DNA. The donor was also found to be negative for signs of secretory paraproteinemia. The patient received $3000 \mathrm{cGy}$ 


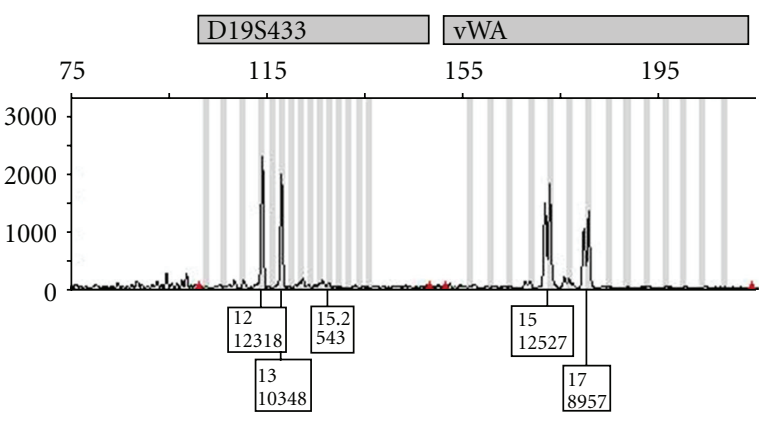

(a)

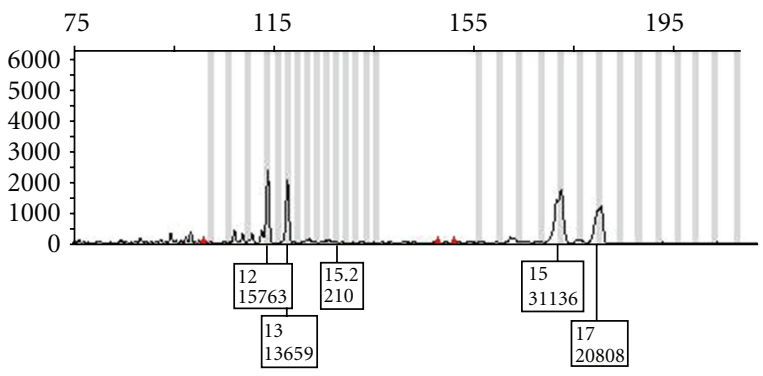

(b)

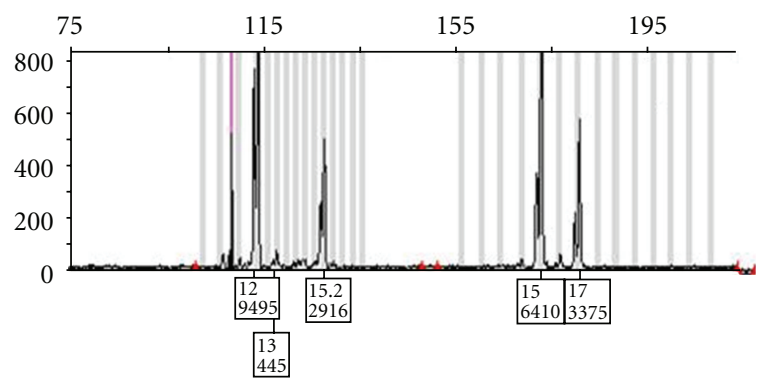

(c)

Figure 1: Chimerism analysis showing complete donor type in $\mathrm{T}$-and non-T-cell lineages in the bone marrow $(\mathrm{a}, \mathrm{b})$ and mixed chimerism in the plasmacytoma (c).

local radiotherapy to T5-T7 level of the spine and high-dose oral dexamethasone. After attaining a CR, it was decided to perform an allogeneic HCT without immunosuppression, instead of the general approach of autologous transplantation, since he had complete donor type of chimerism. Following a nonmyeloablative conditioning with fludarabine and melphalan a hematologic engraftment was achieved. The BM and blood examinations revealed CR for myeloma and a continued complete donor-type chimerism. The patient developed a grade 2 acute GVHD of skin which was controlled with steroids, but acute grade 3 gastrointestinal GVHD required the addition of cyclosporin. Later immunosuppression could be tapered off completely without causing rebound GVHD. He continued in CR until one year after transplantation when he developed progressive mucor sinusitis and infectious meningitis and eventually died.

\section{Discussion}

Posttransplant lymphoproliferative diseases are a heterogenous group of disorders which develop after solid organ or hematopoietic stem cell transplantation as a result of immunosuppression. In contrast to the high incidence of posttransplant lymphomas, PTLDs manifesting as plasma cell myeloma/plasmacytoma are extremely rare. Most of the reported cases have developed after solid organ transplantation, mainly renal transplantation. The incidence of PTLD after allogeneic HCT is $1-2 \%$, mostly diagnosed within the first year and strongly associated with EBV. On the other hand, EBV-negative PTLDs usually occur later [1-5]. The risk of PTLD after HCT increases significantly with T-cell depletion of the donor marrow and T-cell-targeted immunosuppression, unrelated or HLA mismatched grafts, severe acute/chronic GVHD, patient age older than 50 years, and receiving a second transplantation [6]. Transient monoclonal or oligoclonal gammopathies may occur early after transplantation and have been attributed to virus induced B-cell proliferation and insufficient T-cell surveillance. However, they are very rarely transformed into plasma cell neoplasms. Our patient did not possess any of the reported risk factors for PTLD development. The occurrence of plasma cell myeloma was also unrelated to EBV which is in contrast with most of the PTLD occuring after HCT. Although the patient's cellular immunity was not compromised for a long time, how the monoclonal plasma cells could evade the immune surveillance and plasma cell myeloma developed requires explanation. There is always the possibility that this might be a conventional de novo plasma cell myeloma/plasmacytoma because myeloma can also be observed in young patients. In the literature, we could find only two reports of plasma cell myeloma/plasmacytoma developing after allogeneic HCT $[7,8]$.

Although the patient was in complete donor-type chimera when he was retransplanted from the same donor 11 years later with fresh peripheral blood stem cells, he still developed GVHD and required immunosuppression. We were not able to find any reports to guide us in our decision making regarding the immunosuppression strategy at the time of retransplantation. Spontaneous occurrance of autologous GVHD in myeloma patients undergoing autologous HCT has been recently reported [9]. On the other hand, additional lymphocytes in the peripheral blood stem cell product infused from the same donor might have behaved like a donor lymphocyte infusion. This observation challenges the concept of long-term immune tolerance. Recipient antigen presenting cells, which are known to play a critical role in initiating GVHD, were in a tolerant status until the second transplantation [10]. Moreover, the BM microenvironment could be an inciting factor. Still, we cannot exclude the changes in donor and recipient immune repertoire and immunogenicity acquired during the 11 years following the first transplantation which seems to have destroyed the donor versus recipient tolerance while inducing new antigenic targets.

\section{References}

[1] N. S. Majhail, "Old and new cancers after hematopoietic-cell transplantation," Hematology, vol. 2008, no. 1, pp. 142-149, 2008. 
[2] X. Sun, L. C. Peterson, Y. Gong, A. E. Traynor, and B. P. Nelson, "Post-transplant plasma cell myeloma and polymorphic lymphoproliferative disorder with monoclonal serum protein occurring in solid organ transplant recipients," Modern Pathology, vol. 17, no. 4, pp. 389-394, 2004.

[3] R. E. Curtis, L. B. Travis, P. A. Rowlings et al., "Risk of lymphoproliferative disorders after bone marrow transplantation: a multi-institutional study," Blood, vol. 94, no. 7, pp. 22082216, 1999.

[4] V. Leblond, F. Davi, F. Charlotte et al., "Posttransplant lymphoproliferative disorders not associated with Epstein-Barr virus: a distinct entity?" Journal of Clinical Oncology, vol. 16, no. 6, pp. 2052-2059, 1998.

[5] B. P. Nelson, M. A. Nalesnik, D. W. Bahler, J. Locker, J. J. Fung, and S. H. Swerdlow, "Epstein-Barr virus-negative posttransplant lymphoproliferative disorders: a distinct entity?" American Journal of Surgical Pathology, vol. 24, no. 3, pp. 375$385,2000$.

[6] O. Landgren, E. S. Gilbert, J. D. Rizzo et al., "Risk factors for lymphoproliferative disorders after allogeneic hematopoietic cell transplantation," Blood, vol. 113, no. 20, pp. 4992-5001, 2009.

[7] K. Kawakami, S. Miyanishi, Y. Nakano et al., "Post-transplant plasmacytoma without Epstein-Barr virus infection occurring rapidly after unrelated allogeneic bone marrow transplantation," International Journal of Hematology, vol. 88, no. 5, pp. 606-609, 2009.

[8] Y. I. Kim, H. R. Kim, M. G. Shin et al., "Donor cell origin of multiple myeloma occurring after allogeneic haematopoietic stem cell transplantation in a patient with refractory anaemia with ring sideroblast," Journal of Clinical Pathology, vol. 64, no. 3, pp. 265-268, 2011.

[9] H. M. Lazarus, S. R. Sommers, L. M. Arfons et al., "Spontaneous autologous graft-versus-host disease in plasma cell myeloma autograft recipients: flow cytometric analysis of hematopoietic progenitor cell grafts," Biology of Blood and Marrow Transplantation, vol. 17, no. 7, pp. 970-978, 2011.

[10] W. D. Shlomchik, M. S. Couzens, C. B. Tang et al., "Prevention of graft versus host disease by inactivation of host antigen-presenting cells," Science, vol. 285, no. 5426, pp. 412-415, 1999. 


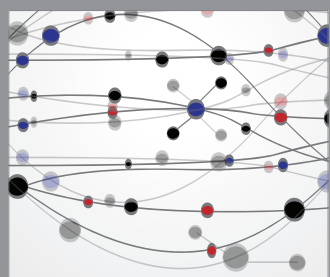

The Scientific World Journal
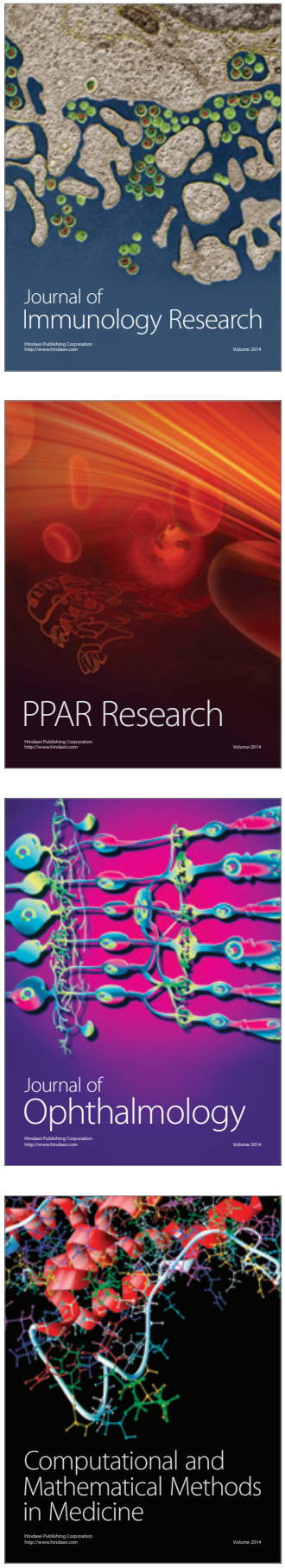

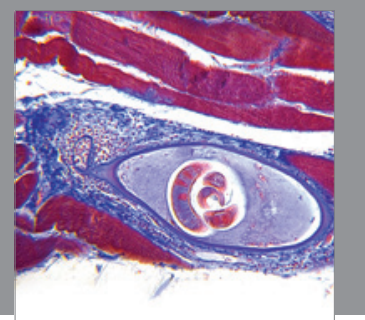

Gastroenterology

Research and Practice
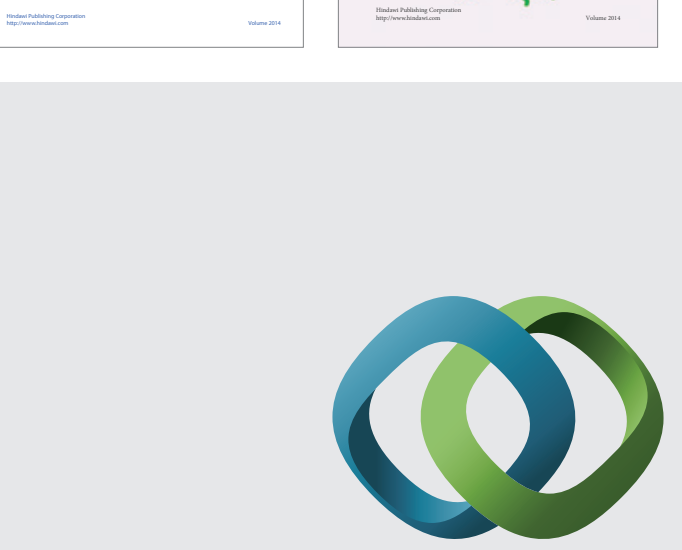

\section{Hindawi}

Submit your manuscripts at

http://www.hindawi.com
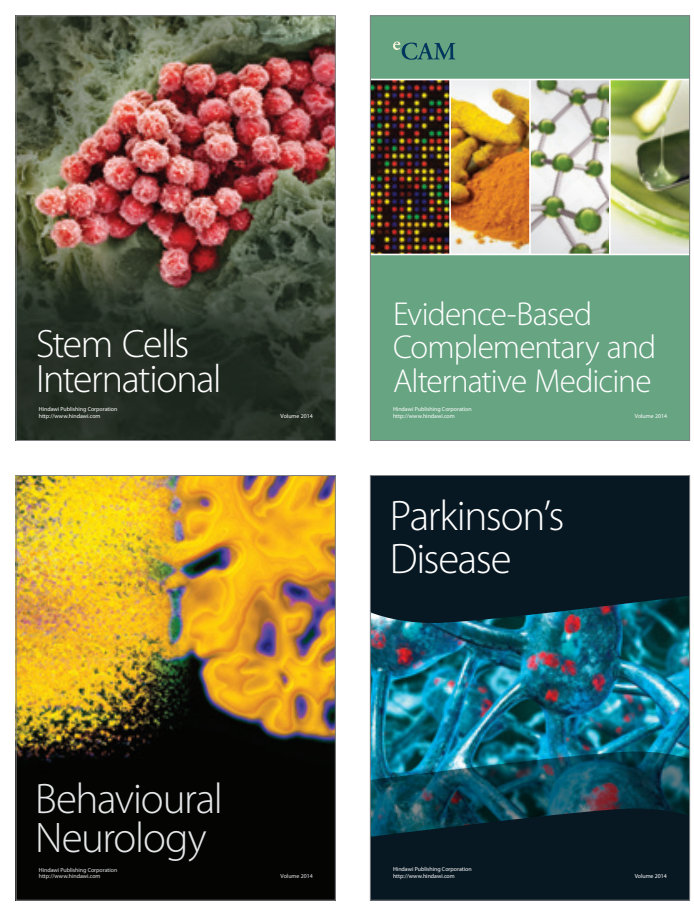

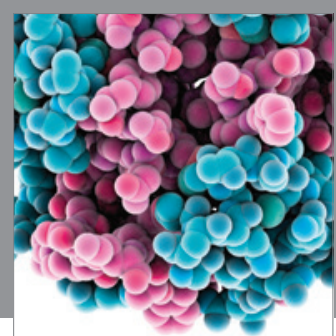

Journal of
Diabetes Research

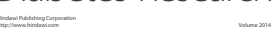

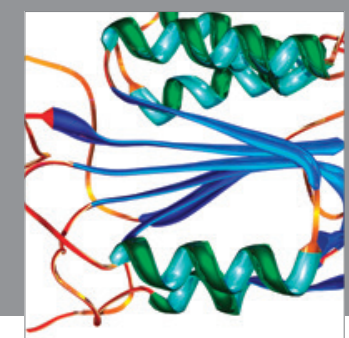

Disease Markers
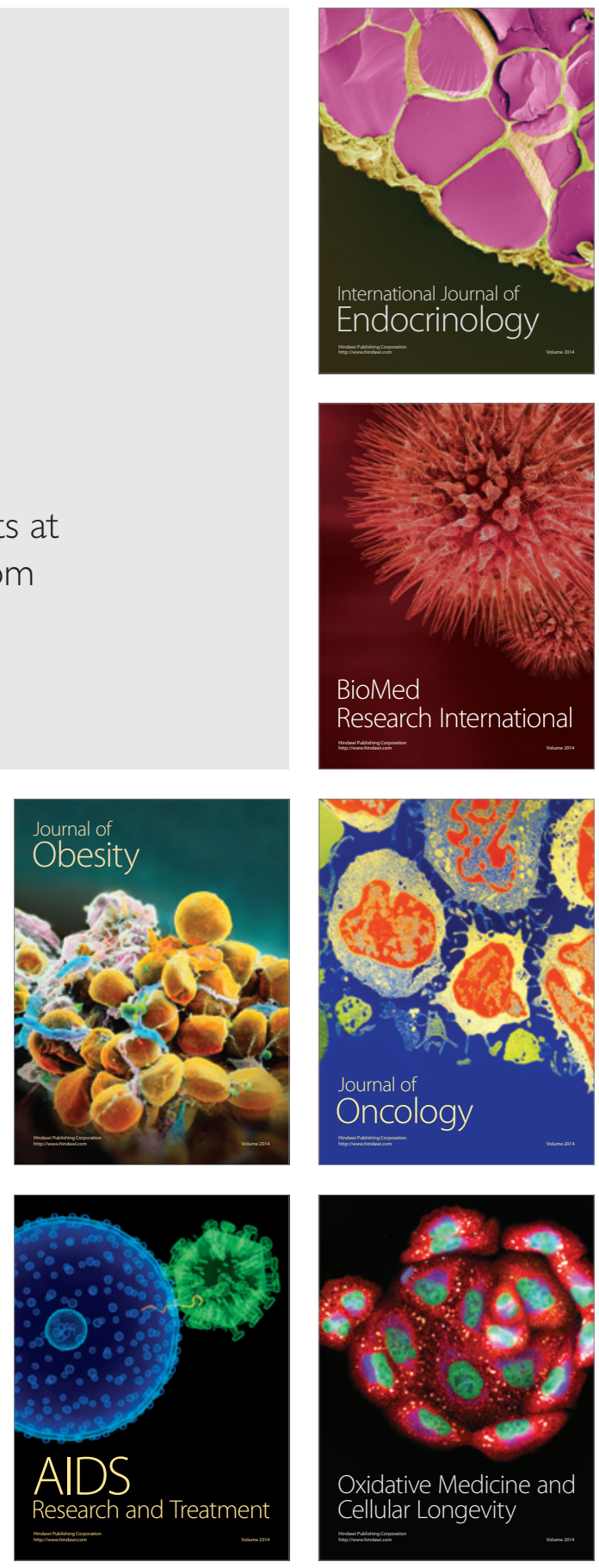